\title{
Prediksi puncak wabah Covid-19 di Indonesia menggunakan model logistik dan forecasting dengan FB Prophet
}

\author{
Fakhoor Izaaz Wildhanrahman*, Chamdan Laylan Abdulbaaqiy, \& Muhammad Farhan \\ Dirhami
}

Institut Pertanian Bogor

*fakhorf@gmail.com

\begin{abstract}
Abstrak. Covid-19 telah menginfeksi banyak orang di Indonesia, dengan jumlah kasus yang dikonfirmasi meningkat setiap harinya, sekitar lebih dari 315.714 orang yang terkonfirmasi positif terpapar Covid-19 di Indonesia (data 7 Oktober 2020 dari situs covid19.go.id). Tim penulis melakukan analisis ini dengan tujuan untuk membuat model rangkaian waktu dari jumlah total orang yang terinfeksi Covid-19 serta memprediksi puncak wabah Covid-19 di Indonesia dengan harapan model yang dihasilkan dapat menjadi pedoman awal dalam persiapan menghadapi puncak wabah Covid-19 di Indonesia. Tim penulis melakukan analisis dengan dua model yakni model logistik dan model forecasting dengan FB Prophet. Prediksi menggunakan model logistik didapatkan hasil jumlah kasus maksimal (saat kondisi puncak) di Indonesia sebesar 669.595, dengan puncak wabah terjadi setelah 870 hari (dihitung mulai tanggal 07 Oktober 2020), yakni pada tanggal 22 Juni 2022. Hal tersebut terbukti dan dapat dibandingkan dengan hasil analisis forecasting dengan FBProphet. Pada analisis forecasting menggunakan FB Prophet didapatkan hasil bahwa kasus terinfeksi Covid-19 di Indonesia akan terus naik, analisis ini menghasilkan prediksi bahwa pada tanggal 22 Oktober 2020 akan terdapat 375.393 orang yang terinfeksi Covid-19 di Indonesia.
\end{abstract}

Kata kunci: covid-19, fb prophet, forecasting, model logistik, model eksponensial

\begin{abstract}
Covid-19 has infected many people in Indonesia, with the number of confirmed cases increasing every day; around 315,714 people have been confirmed positive for Covid-19 (data on 7 October 2020 from the covid19.go.id website). The author's team conducted this analysis intending to create a time series model of the total number of people infected with Covid-19 and predict the peak of the Covid-19 outbreak in Indonesia with the hope that the resulting model can be an initial guideline in preparation for the peak of the Covid-19 outbreak in Indonesia. The author's team analyzed logistic models and forecasting models with FB Prophet. Prediction using the logistic model results in the maximum number of cases (during peak conditions) in Indonesia of 669,595, with the peak of the outbreak occurring after 870 days (calculated starting on October 7, 2020), namely on June 22, 2022. This is proven and can be compared with the results of forecasting analysis with FBProphet. In a forecasting analysis using FB Prophet, the results show that cases of Covid-19 infection in Indonesia will continue to rise. This analysis results in a prediction that on October 22, 2020, there will be 375,393 people infected with Covid-19 in Indonesia.
\end{abstract}

Keywords: covid-19, fb prophet, forecasting, logistics model, exponential model

To cite this article: Wildhanrahman, F. I., C. L. Abdulbaaqiy., \& M. F. Dirhami. 2020. Prediksi puncak wabah Covid-19 di Indonesia menggunakan model logistik dan forecasting dengan FB Prophet. Unri Conference Series: Community Engagement 2: 352-358. https://doi.org/10.31258/unricsce.2.352-358

(C) 2020 Authors

Peer-review under responsibility of the organizing committee of Seminar Nasional Pemberdayaan Masyarakat 2020 


\section{PENDAHULUAN}

Pada awal tahun 2020, dunia digemparkan dengan merebaknya virus baru yaitu coronavirus jenis baru (SARS CoV-2019) dan penyakitnya disebut Coronavirus disease 2019 (Covid-19). Diketahui, asal mula virus ini berasal dari Wuhan, Tiongkok dan ditemukan pada akhir bulan desember tahun 2019. Pada awalnya, data epidemiologi menunjukkan 66\% pasien berkaitan dengan salah satu pasar seafood atau live market di Wuhan, Provinsi Hubei Tiongkok (Huang, et.al., 2020).

Sampel isolat dari pasien diteliti dengan hasil menunjukkan adanya infeksi coronavirus, jenis betacoronavirus tipe baru, diberi nama 2019 novel Coronavirus (2019-nCoV). Pada tanggal 11 Februari 2020, World Health Organization memberi nama virus baru tersebut Severe acute respiratory syndrome coronavirus2 (SARS-CoV-2) dan nama penyakitnya sebagai Coronavirus disease 2019 (Covid-19) (WHO, 2020). Pada mulanya transmisi virus ini belum dapat ditentukan apakah dapat melalui antara manusia-manusia. Jumlah kasus terus bertambah seiring dengan berjalannya waktu. Selain itu, terdapat kasus 15 petugas medis terinfeksi oleh salah satu pasien. Salah satu pasien tersebut dicurigai kasus "super spreader". (Channel News Asia, 2020). Akhirnya dikonfirmasi bahwa transmisi pneumonia ini dapat menular dari manusia ke manusia (Relman, 2020). Sampai saat ini virus ini dengan cepat menyebar masih misterius dan penelitian masih terus berlanjut.

Kejadian luar biasa oleh Coronavirus bukanlah merupakan kejadian yang pertama kali. Tahun 2002 severe acute respiratory syndrome (SARS) disebabkan oleh SARS-coronavirus (SARS-CoV) dan penyakit Middle East respiratory syndrome (MERS) tahun 2012 disebabkan oleh MERS-Coronavirus (MERS-CoV) dengan total kumulatif kasus sekitar 10.000 (1000an kasus MERS dan 8000an kasus SARS). Mortalitas akibat SARS sekitar 10\% sedangkan MERS lebih tinggi yaitu sekitar 40\%. (PDPI, 2020).

Covid-19 telah menginfeksi banyak orang di Indonesia, dan jumlah kasus yang dikonfirmasi meningkat secara eksponensial. Indonesia telah meningkatkan peringatan coronavirus-nya ke "Darurat Nasional" hingga waktu yang belum ditentukan. Pulau Jawa, khususnya Jakarta, ibu kota Indonesia, adalah wilayah yang paling terpengaruh oleh coronavirus, Jawa Barat dan Jawa Timur juga menjadi daerah yang banyak terdapat pasien positif Covid-19. Indonesia juga diprediksi menjadi salah satu cluster Covid-19 terbesar di dunia karena memiliki sekitar 315.714 ribu lebih pasien positif Covid-19 (data 7 Oktober 2020). Hingga saat ini, banyak analisis yang dilakukan oleh para ahli statistik, akademisi, institusi, sampai lembaga negara untuk memprediksi puncak wabah Covid-19 dan akhir wabah Covid-19 di Indonesia. Pada analisis kali ini, tim penulis turut serta dalam memprediksi puncak wabah Covid-19 di Indonesia.

Ruang lingkup penelitian ini adalah dataset pertumbuhan virus corona di Indonesia yang diperoleh dari situs databoks.katadata.co.id pada tanggal 07 Oktober 2020. Dataset tersebut dikumpulkan dari data beberapa portal online yang tersedia untuk mengumumkan informasi Covid-19 di indonesia yang bersifat publik. Dataset ini pula dapat diperbaharui data nya sesuai dengan data yang terdapat pada portal online utama yakni website resmi pemerintah covid19.go.id.

Tujuan analisis ini adalah untuk membuat model rangkaian waktu dari jumlah total orang yang terinfeksi Covid-19 serta memprediksi puncak wabah Covid-19 di Indonesia. Harapan analisis ini adalah model yang dihasilkan dapat menjadi pedoman awal persiapan menghadapi puncak wabah Covid-19 di Indonesia, serta diharapkan dapat mendukung perjuangan berkelanjutan dalam melawan pandemi Covid-19 di Indonesia.

\section{METODE PENERAPAN}

\section{Dataset}

Dataset yang digunakan dihimpun dari beberapa data yang berbeda diantaranya adalah data total kasus terkonfirmasi positif Covid-19 pada databoks.katadata.co.id serta update data sampai dengan tanggal 7 Juni 2020 pada situs covid19.go.id. Dataset tersebut bersifat time series dengan atribut yang dipergunakan pada analisis ini adalah date (tanggal) dan Total Kasus (akumulasi data terkonfirmasi positif Covid-19 tiap hari).

\section{Tahapan Kegiatan}

Tahapan kegiatan analisis ini diawali dengan pra-analisis data dengan peninjauan dataset serta pencarian referensi. Langkah berikutnya adalah pra-proses data, pada langkah ini dilakukan pengubahat format pada atribut date yang semula berupa format tanggal menjadi jumlah hari yang dimulai dari 0. Setelah pra-proses data dilakukan, dataset akan dianalisis menjadi dua pemodelan, yakni model logistik, dan model forecasting dengan FBProphet. Pemodelan pertama dengan model logistik akan dilakukan perumusan model logistik, kemudian dilakukan analisis dengan prediksi puncak pada grafik model logistik. Tahapan berikutnya adalah plotting model logistik dan eksponensial serta membandingkan hasil nya. Selanjutnya, dilakukan analisis 
koefisien determinasi dan analisis residual pada model logistik. Pemodelan kedua adalah model forecasting dengan FB Prophet, langkah awal yang dilakukan adalah transformasi dataset ke dalam format FB Prophet, selanjutnya dilakukan perumusan model FB Prophet, dan terakhir dilakukan prediksi. Tahapan akhir dari analisis ini adalah penarikan kesimpulan dari kedua pemodelan yang telah dilakukan.

\section{Model Logistik}

Model logistik telah banyak digunakan dalam menggambarkan pertumbuhan suatu populasi pada patogen. Infeksi Covid-19 dapat dianalogikan pula sebagai pertumbuhan populasi suatu agen patogen, sehingga model logistik dapat menggambarkannya. Model ini sangat dikenal di kalangan ilmuan data karena digunakan dalam klasifikasi regresi logistik dan juga digunakan sebagai fungsi aktivasi jaringan syaraf.

$$
f(x, a, b, c)=\frac{c}{1+e^{-(x-b) / a}}
$$

Keterangan:

- $\mathrm{x}$ adalah waktu

- a adalah laju infeksi Covid-19

- b adalah hari maksimum terjadinya infeksi Covid-19

- $\mathrm{c}$ adalah jumlah orang (yang tercatat) terinfeksi Covid-19

Pada nilai waktu (x) yang tinggi, jumlah orang yang terinfeksi akan semakin dekat ke-titik c,maka pada titik itulah dapat dikatakan pula infeksi Covid-19 telah berakhir. Fungsi ini juga memiliki titik belok (b), yaitu titik dimana turunan pertama mulai berkurang (yaitu puncak setelah infeksi mulai menjadi tidak agresif dan mulai menurun).

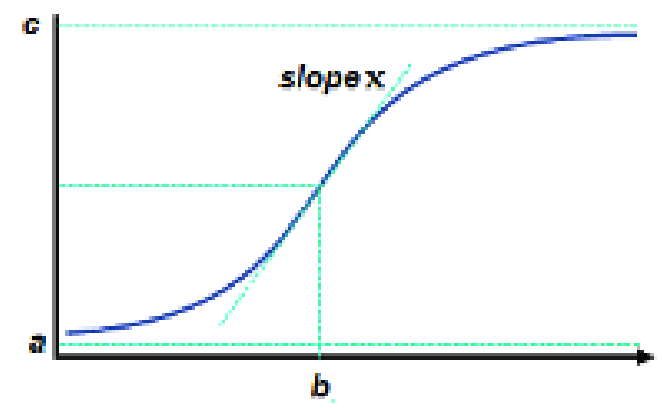

Gambar 1. Teori model logistik

\section{Model forecasting dengan FB Prophet}

Prophet adalah prosedur untuk memprediksi data deret waktu berdasarkan model aditif dimana trend nonlinear cocok dengan data tahunan, mingguan, harian, musiman, dan efek liburan. Forecasting FB Prophet bekerja paling baik dengan deret waktu yang memiliki efek musiman (seasonal effects yang kuat dan beberapa data musim secara historis. FB Prophet kuat dalam kehilangan data dan pergeseran tren, serta biasanya dapat menangani outlier dengan baik.

\section{Lingkungan pengembangan}

Pada analisis ini, tim penulis menggunakan website Google Collaboratory dan Notebook pada Kaggle dengan bahasa pemrograman Python 3. Kedua website tersebut dipilih karena dapat memiliki beberapa kelebihan diantaranya adalah dapat mengerjakan analisis secara tim, menyediakan berbagai package dan library, serta dapat gratis secara digunakan. Kemudian, pada analisis ini pula tim penulis menggunakan beberapa package diantaranya pandas, numpy, curve_fit, fsolve, matplotlib, datetime dan library FB Prophet dari Facebook. 


\section{HASIL DAN KETERCAPAIAN SASARAN}

\section{Pra-Proses data}

Pra-proses data dilakukan dengan pengubahan format tanggal menjadi jumlah hari. Pada analisis ini, tim penulis menggunakan tanggal 2 Maret 2020 (Kasus pertama kali terdeteksi pasien positif Covid-19 di Indonesia) dan menetapkannya sebagai hari ke-satu (ditulis 0 ).

\section{Implementasi model logistik}

Tim penulis menerapkan model logistik pada dataset menggunakan fungsi matematika pada Python seperti pada gambar berikut.

\section{def logistic model( $\mathrm{x}, \mathrm{a}, \mathrm{b}, \mathrm{c})$ : return $\mathrm{c} /(1+\mathrm{np} \cdot \exp (-(\mathrm{x}-\mathrm{b}) / \mathrm{a}))$}

Gambar 2. Fungsi mode logistik pada python

Perkiraan nilai pamaterer dan starting error dari dataset, digunakan fungsi curve fit dari library scipy pada python, didapatkan hasil seperti pada tabel 1. Fungsi curve fit yang dipakai akan mengembalikan matriks covariance, dimana nilai diagonal dari setiap nilai parameter. Maka dari itu, diperlukan perhitungan kesalahan standar dengan mengambil akar kuadrat dari setiap parameter.

Tabel 1. Hasil model logistik

\begin{tabular}{lll}
\hline Parameter & Nilai & Standar Error \\
\hline a & 42819,000 & 0,569 \\
b & 222,413 & 2,912 \\
c & 644916,605 & 24618,628 \\
\hline
\end{tabular}

\section{Koefisien Determinasi Model Logistik}

Koefisien Determinasi ( $\left.\mathrm{R}^{\wedge} 2\right)$ digunakan sebagai ukuran seberapa baik hasil observasi direplikasi oleh model. $\mathrm{R}^{\wedge} 2$ adalah proporsi dari varians dalam variabel dependen yang dapat diprediksi dari variabel independen. Nilai $\mathrm{R}^{\wedge} 2$ dapat dinyatakan dengan rumus berikut:

$$
\bar{R}^{2}=1-\frac{S S_{\mathrm{res}} / \mathrm{df}_{e}}{S S_{\text {tot }} / \mathrm{df}_{t}}
$$

Gambar 4. Fungsi koefisien determinasi

Analisa pada koefisien determinasi pada model logistik mendapatkan nilai sebesar 0.99779, atau dapat dikatakan pula bahwa variabel bebas dalam menjelaskan variabel terikatnya adalah sebesar $99 \%$.

\section{Analisis residual model logistik}

Residual adalah perbedaan antara setiap titik eksperimen dan titik teoritis yang sesuai. Analisis residu dilakukan dengan kedua model untuk memverifikasi fitting curve terbaik. Pada perkiraan pertama, semakin rendah mean squared error (MSE) antara data teoritis dan eksperimen, maka akan semakin baik kesesuaian nya. Dalam analisa ini, didapatkan mean squared error pada model logistik dengan nilai sebesar 17093100,381. Apabila hasil analisis residual ini disandingkan dengan logika, maka akan sangat mungkin, karena infeksi COVID-19 akan berakhir di masa depan, bahkan jika semua orang di Indonesia akan terinfeksi, manusia akan mengembangkan pertahanan kekebalan yang tepat untuk menghindari infeksi virus kedua kalinya. Hal tersebut dapat dikatakan benar, selama virus Covid-19 tidak bermutasi terlalu banyak (seperti virus influenza).

\section{Plot model logistik dan prediksi}

Analisis model logistik yang telah dilakukan pada tahap sebelumnya dilanjutkan dengan membuat plot serta disandingkan dengan database awal (real data). Plotting dilakukan dengan menggunakan package matplotlib pada Python. 


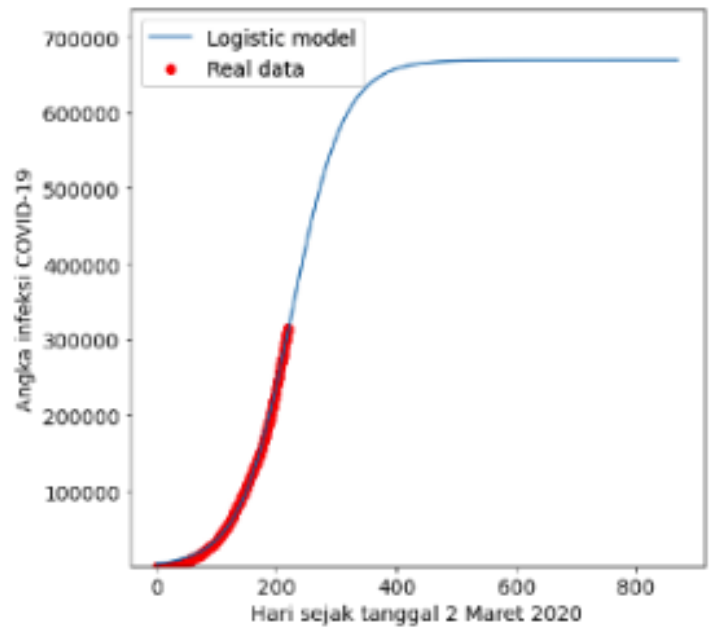

Gambar 5. Plot model logistik dan dataset awal

sol - int (fsolve(lambda x ; logistic_model $(x, a, b, c)-\operatorname{int}(c), b)$ )

Gambar 6. Fungsi prediksi pada model logistik

Dengan menerapkan fungsi prediksi pada model logistik, didapatkan prediksi puncak wabah Covid-19 di Indonesia adalah 870 hari setelah tanggal 07 Oktober 2020 (tanggal terakhir pengambilan data) yakni pada tanggal 22 Juni 2022. Hasil prediksi dengan model logistik ini juga memperkirakan jumlah kasus maksimal orang yang terinfeksi Covid-19 adalah sebanyak 669.595 orang.

\section{Implementasi model forecasting dengan FB Prophet}

Langkah awal dalam melakukan pemodelan forecasting dengan FB Prophet adalah dengan melihat trend dari data kasus Covid-19 di Indonesia. Tren dari data tersebut dapat dilihat secara mudah dengan membuat plotting dalam bentuk gambar. Berikut ini adalah plot dari trend data kasus Covid-19 di Indonesia.

Trend

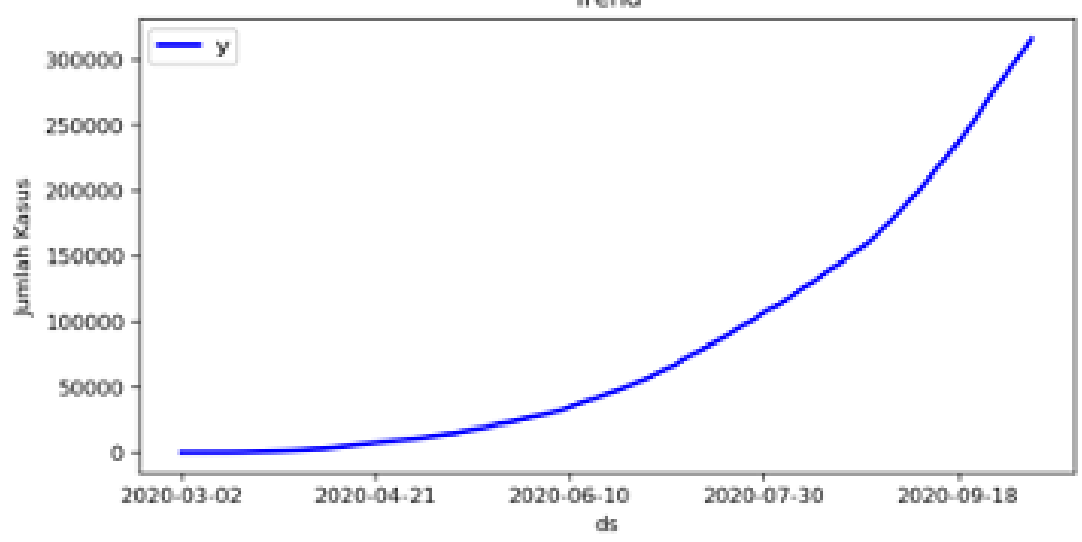

Gambar 7. Trend Kasus Covid-19 di Indonesia

Dapat dilihat bahwa trend kasus Covid-19 di Indonesia terus meningkat setiap hari nya. Kita dapat memprediksi selama beberapa hari kedepan, apakah kasus Covid-19 di Indonesia akan terus meningkat atau cenderung menurun. FB Prophet dapat memprediksi hal tersebut karena mendukung model forecasting yang bersifat time series. Maka dari itu, hanya atribut total kasus dan tanggal pada data yang dipakai untuk pemodelan forecasting dengan FB Prophet.

Setelah mendapatkan trend pada data, selanjutnya dilakukan perumusan model prediksi pada data menggunakan package yang terdapat pada FB Prophet. Pada implementasi ini, tim penulis menerapkan 
beberapa parameter yang akan dimasukkan untuk menganalisis prediksi, diantaranya adalah change prior scale sebesar 0,3 , change point range sebesar 0,95 , dan menggunakan prediksi dengan sasaran daily seasonality.

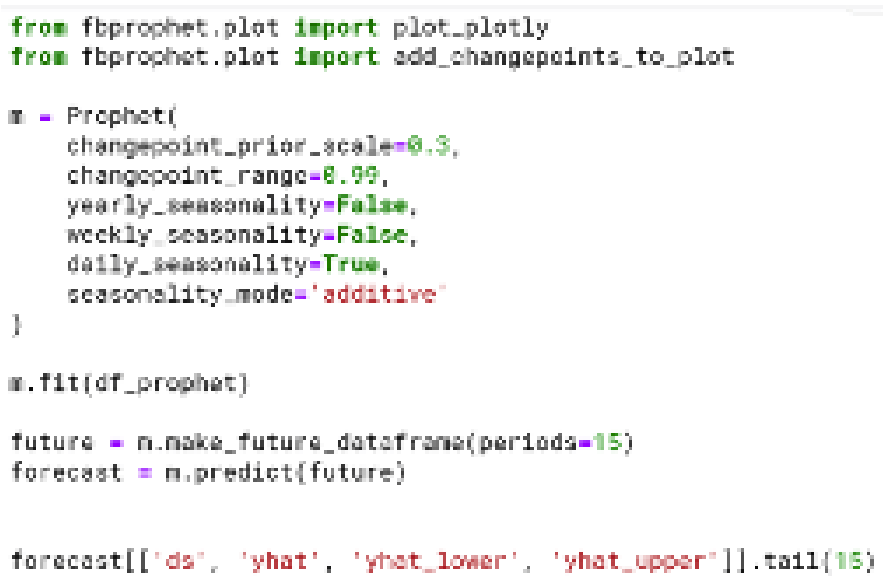

Gambar 8. Implementasi FB Prophet pada Data

Setelah menerapkan FB Prophet pada data, selanjutnya dilakukan penggambaran prediksi kasus Covid-19 dengan menggunakan fungsi plotting yang terdapat pada Python.

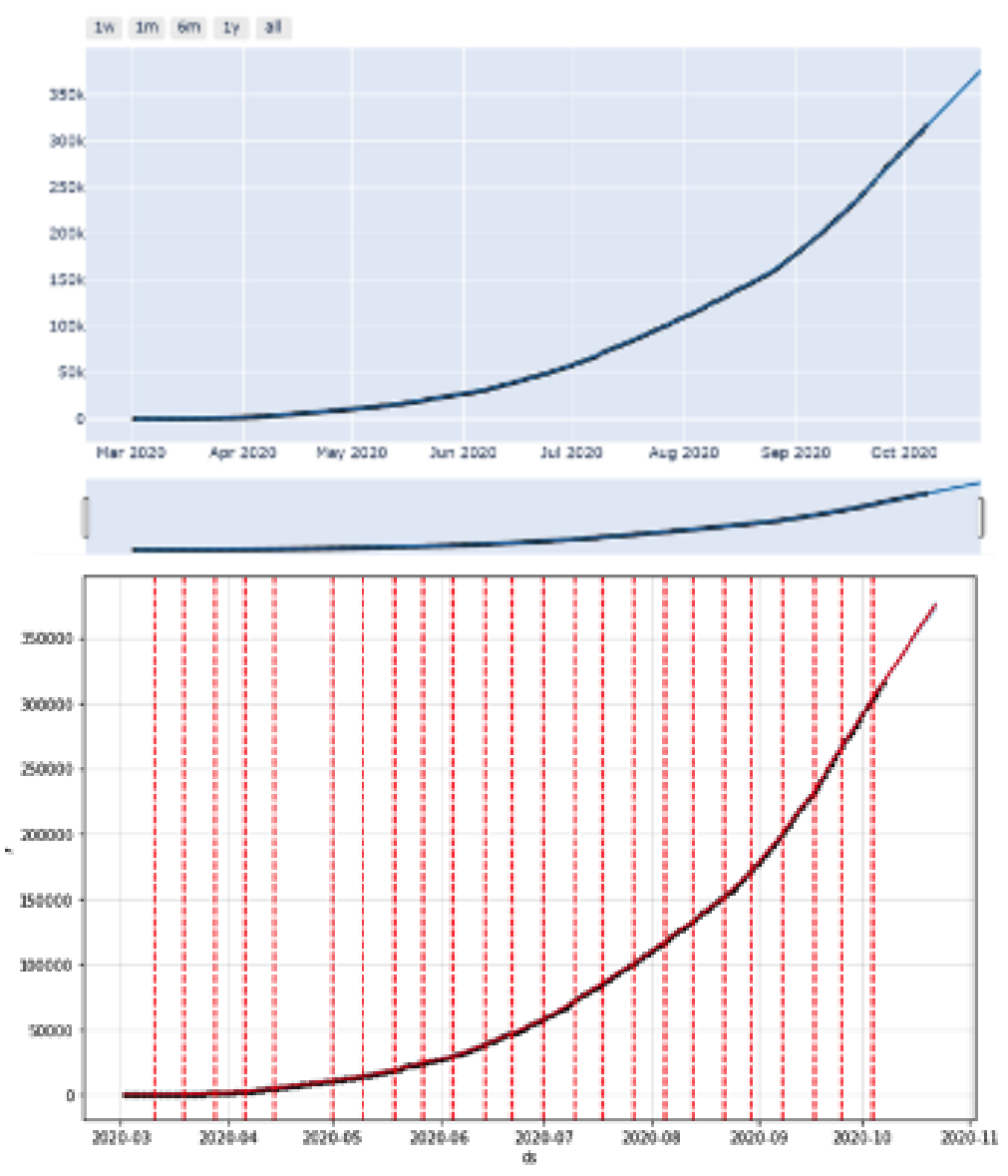

Gambar 9. Grafik Prediksi Kasus Covid-19 di Indonesia

Berdasarkan pemodelan forecast menggunakan FB Prophet, didapatkan hasil bahwa selama beberapa hari kedepan (sejak tanggal 07 Oktober 2020), kasus positif covid-19 di Indonesia akan terus meningkat. Sebagai 
contoh, pada tanggal 22 Oktober 2020, melalui pemodelan ini diprediksi bahwa kasus covid-19 di Indonesia sebanyak 375.393 total kasus positif.

\section{KESIMPULAN}

Berdasarkan prediksi menggunakan model logistik, jumlah kasus maksimal (yang diharapkan) di Indonesia adalah 669.595 dengan perkiraan puncak wabah Covid-19 di Indonesia terjadi pada tanggal 22 Juni 2022. Akan tetapi ada satu hal yang menjadi perhatian penting pada analisis ini, apabila dilakukan penyesuaian kurva logistik setiap hari sejak awal infeksi, maka setiap harinya akan mendapatkan nilai parameter yang berbeda. Jumlah orang yang terinfeksi pada akhirnya meningkat, hari infeksi maksimum sering hari ini atau hari berikutnya (yang kompatibel dengan kesalahan standar 1 hari pada parameter ini). Karena itu, model logistik merupakan pemodelan yang paling logis, bentuk kurva mungkin akan berubah karena efek eksogen seperti terjadinya infeksi baru, tindakan pemerintah untuk mengikat infeksi dan sebagainya. Prediksi akan lebih akurat jika data yang disediakan lebih baik dan puncak dari penyebaran telah terlewati. Sedangkan, hasil yang didapatkan pada model forecasting dengan FB Prophet, memang hasil yang didapatkan bahwa grafik kasus terinfeksi Covid-19 di Indonesia akan terus naik. Prediksi pada tanggal 22 Oktober 2020 terdapat 375.393 orang yang terinfeksi Covid-19 di Indonesia. Analisis yang dilakukan tim penulis kali ini belum dapat dikatakan sebagai analisis yang representatif, dikarenakan untuk analisis dengan pemodelan logistik, prediksi puncak wabah Covid-19 akan terus bergeser apabila dataset diperbaharui. Analisis menggunakan model logistik dapat optimal digunakan apabila representasi dataset pada grafik menunjukkan trend yang menurun, artinya kondisi grafik telah mencapai titik puncak dan menuju titik 0. Apabila model logistik menggunakan dataset yang telah menunjukkan trend yang menurun, maka representasi dari prediksi akhir wabah Covid-19 dapat dilakukan dan mendapatkan hasil yang optimum.

\section{UCAPAN TERIMA KASIH}

Selama pengerjaan analisis ini, tim penulis banyak menghadapi masalah dan hambatan, sehingga banyak pihak yang turut membantu dan mendukung penulis dalam menyelesaikan analisis ini. Oleh karena itu, penulis ingin memberikan apresiasi berupa ucapan terima kasih kepada Prof. Dr. Imas Sukaesih Sitanggang, S.Si, M.Kom selaku koordinator mata kuliah data mining beserta tim asisten praktikum data mining yang telah berkenan untuk membimbing tim penulis dalam menyelesaikan analisis ini.

\section{DAFTAR PUSTAKA}

Channel News Asia. 2020. Wuhan virus outbreak: 15 medical workers infected, 1 in critical condition. [Internet]. Diakses 06 Oktober 2020. [https://www.channelnewsasia.com/news/asia/wuhanpneumonia-outbreak-healthworkers-coronavirus-12294212].

Huang, C., Wang, Y., Li, X., Ren, L., Zhao, J., Zan,g Li., Fan, G., etc. 2020. Clinical features of patients infected with 2019 novel coronavirus in Wuhan, China. The Lancet.

Malato, G. 2020. Covid-19 infection in Italy. Mathematical models and predictions, A comparison of logistic and exponential models applied to Covid-19 virus infection in Italy. [Internet]. Diakses 06 Oktober 2020. [https://towardsdatascience.com/covid-19-infection-in-italy-mathematical-models-and-predictions$7784 \mathrm{~b} 4 \mathrm{~d} 7 \mathrm{dd} 8 \mathrm{~d}]$.

Perhimpunan Dokter Paru Indonesia. 2020. Panduan Praktik Klinis: Pneumonia 2019-nCoV. PDPI: Jakarta.

Relman, E. 2020. Business insider Singapore. Cited Jan 28th2020. Available on: https://www.businessinsider.sg/deadly-china-wuhan-virusspreading-human-to-human-officials-confirm-2020$1 /$ ? $=$ US\&IR=T

Robson, W. 2019. Intro to Facebook Prophet, Walk-thru Example \& Repo - Everything you need to know when starting out with Facebook's time series forecasting tool. [Internet]. Diakses 06 Oktober 2020. [https://medium.com/future-vision/intro-to-prophet-9d5b1cbd674e]. 